\title{
GAMBARAN DISIPLIN DAN BUDAYA KERJA TERHADAP PERILAKU KEWARGAAN ORGANISASIONAL KARYAWAN PT. INTI (PERSERO) DI BANDUNG
}

\author{
Ngindi Fadhilah Pratiwi \\ Universitas Pendidikan Indonesia \\ ngindi.fadhilah.pratiwi@student.upi.edu \\ Syamsul Hadi Senen \\ Universitas Pendidikan Indonesia \\ syamsulhadisenen@upi.edu \\ Sumiyati \\ Universitas Pendidikan Indonesia \\ sumiyati@upi.edu
}

\begin{abstract}
ABSTRAK
Tujuan - Tujuan penelitian ini adalah untuk mengetahui gambaran disiplin, budaya kerja dan perilaku kewargaan organisasional karyawan.

Desain / metodologi / pendekatan - Desain penelitian adalah cross-sectional. Penelitian ini menggunakan pendekatan deskriptif dengan metode explanatory survey. Unit analisis karyawan sebanyak 90 orang. Pengumpulan data dengan menggunakan kuesioner. Teknik analisis yang digunakan adalah teknik deskriptif dengan menggunakan distribusi frekuensi.

Temuan - Berdasarkan hasil penelitian, didapatkan hasil bahwa disiplin dalam kategori sesuai dengan perolehan skor $65,5 \%$, budaya kerja berada pada kategori tinggi dengan perolehan skor $72,8 \%$, dan perilaku kewargaan organisasional karyawan berada pada kategori sesusi dengan perolehan skor $66,2 \%$.

Orisinalitas / nilai - Penelitian ini memberikan dasar untuk memahami isu-isu disiplin kerja, budaya kerja, dan perilaku kewargaan organisasional karyawan. Perbedaan penelitian ini dengan penelitian sebelumnya adalah pada objek, variabel, teori, serta referensi yang digunakan oleh peneliti dengan peneliti sebelumnya.
\end{abstract}

Kata Kunci : Disiplin, budaya kerja, perilaku kewargaan organisasional Jenis Artikel : Studi Kasus

\begin{abstract}
Purpose - The purpose of this research is to know the decription of dicipline, work culture and organizational behavior citizenship.

Design/methodology/approach - The Research design is cross sectional. This research is using descriptive approach with explanatory survey method. The analysis unit is 90 employees. Collecting the data is using questionnaire. Analysis technique used is descriptive technique with using frequency distribution.

Finding - Based on the result of research, the results obtained that work dicipline in the category is appropriate with a score 65,5\%, work culture is in the high category with a score 72,8\%, and organizatonal citizenship behavior is in high category with a score 66,2\%.

Originality/value - This research giving a basic for understanding work dicipline, work culture and issues on organizatonal citizenship behavior. The difference of this research with the previous research are on the object, variable, theory and references.
\end{abstract}

Keywords: Dicipline, Work Culture, Organizatonal Citizenship Behavior Article Type : Case Study 


\section{PENDAHULUAN}

Kunci keberhasilan yang sangat penting untuk mencapai keberhasilan bagi tercapainya tujuan organisasi adalah sumber daya manusia. Sumber daya manusia sebagai bagian esensial dari perusahaan atau organisasi yang harus diperhatikan agar karyawan sebagai bagian dari SDM dapat memberikan kontribusinya secara optimal (Senen, Sumiyati, \& Masharyono, 2016). Sumber daya manusia salah satu sumber daya yang dituntut untuk terus meningkatkan kinerjanya agar dapat mencapai tujuan organisasi dan meningkatkan profit organisasi (Badu, 2013). Selain itu, perusahaan harus mampu memberikan strategistrategi penunjang yang dapat meningkatkan potensi karyawannya sehingga kinerja organisasi dapat berjalan secara optimal (Armstrong, 2014).

Perusahaan dituntut untuk mampu memberikan dorongan secara psikologis dalam hal menanamkan cara bekerja yang baik kepada karyawan yang bertujuan agar karyawan dapat mempunyai karakter atau perilaku yang baik bagi perusahaan, sehingga terdapat koordinasi yang baik antara karyawan dan perusahaan (Robbins, 2013). Setiap organisasi membutuhkan karyawan yang melakukan tugas ekstra diluar tugas wajib pekerjaannya, hal ini menunjukkan bahwa karyawan memiliki rasa peduli terhadap rekan kerjanya yang lain (Ngadiman, 2013). Organisasi yang berhasil adalah organisasi yang bekerja secara efektif, dimana untuk mencapai keefektifan tersebut sangat diperlukan kerja sama tim yang baik antar karyawan, dengan begitu karyawan tidak akan merasa enggan untuk membantu rekanrekan di tempat kerja mereka dan melakukan tugastugas melebihi dari tugas mereka sebenarnya mencerminkan perilaku kewargaan organisasional (Wibowo, 2014).

Organisasi yang efektif dan efisien akan tercapai jika karyawan menunjukkan Organizational Citizenship Behavior atau Perilaku kewargaan organisasional, pada masa sekarang ini merupakan fenomena kompleks yang muncul sebagai aspek yang penting dari perilaku manusia di tempat kerja (Sardjono, 2014). Perilaku kewargaan organisasional yang baik ditandai dengan sikap membantu orang lain yang menghadapi masalah dalam pekerjaannya, hal ini setidaknya akan berpengaruh terhadap penurunan biaya operasional dan waktu penyelesaian pekerjaan lebih cepat serta penggunaan sumber daya lebih optimal (Badu, 2013). Perilaku ini cenderung melihat seorang karyawan sebagai makhluk sosial, dibandingkan sebagai makhluk individual yang lebih mementingkan diri sendiri (Asamani, 2013).

Perilaku kewargaan organisasional secara konseptual memberikan kontribusi bagi sebuah organisasi (Sardjono, 2014). Permasalahan kurangnya penerapan perilaku kewargaan organisasional pada perusahaan PT. INTI (Persero) mengalami masalah yaitu setiap sektor tidak menjalin kerjasama yang komperhensif hal ini dibuktikan dengan laporan data absensi mangkir dan pulang cepat yang meningkat sehingga kurangnya rasa kepedulian karyawan terhadap rekanan kerja yang lain. Selain itu, karyawan hanya menyelesaikan job desk yang ditentukan saja, sehingga tidak memiliki insiatif membantu rekan yang mengalami kesulitan dalam pekerjaannya. Hal ini dapat dilihat dari realisasi pencapaian kinerja perusahaan yang tidak memenuhi target perusahaan.

Perilaku kewargaan organisasional dapat diatasi dengan cara meningkatkan penerapan budaya kerja dan disiplin, karena melalui peran dan penerapan budaya kerja dan peningkatan penerapan disiplin maka sumber daya manusia yang dimiliki perusahaan akan menimbulkan rasa memiliki dan loyalitas karyawan terhadap perusahaan dalam melaksanakan pekerjan yang diberikan dengan adanya solusi yang ada maka diharapkan penelitian mampu berkorelasi dengan solusi yang ada di perusahaan (Sardjono, 2014). Perilaku kewargaan organisasional dapat dijadikan sebagai hasil potensial dari budaya kerja yang positif. Budaya kerja yang positif menekankan pada pembangunan karakteristik karyawan pada saat melaksanakan tugas, sehingga dapat menumbuhkan disiplin yang baik terhadap tugasnya. Hal ini dapat diindikasikan bahwa penerapan budaya kerja dan disiplin dapat meningkatkan perilaku kewargaan organisasional. Keseluruhan persepsi budaya kerja dan disiplin kerja didalam organisasi akan mempengaruhi perilaku kewargaan organisasional (Naidoo, Pervashnee \& Martins, Nico,2014; Shehada, 2015).

Perilaku kewargaan organisasional yang rendah di PT. INTI (Persero) akan berdampak langsung pada berkurangnya efektivitas dan efisiensi perusahaan. Karyawan dengan perilaku kewargaan organisasional yang rendah di PT. INTI (Persero) ditandai dengan perilaku pasif karyawan dalam melakukan pekerjaan. Karyawan akan bekerja sesuai dengan tuntutan tugas yang diemban saja. Namun, tidak menumbuhkan kesediaan dalam melakukan tugas diluar tuntutan tugas tersebut. Pada kenyataannya kesediaan karyawan dalam pekerjaan diluar tuntutan tugas karyawan akan mendorong usaha organisasi tersebut menuju pada kesuksesan. Oleh karena itu, perlu adanya upaya yang dilakukan oleh PT. INTI (Persero) dalam meningkatkan perilaku kewargaan organisasi, yaitu melalui peningkatan disiplin dan budaya kerja.

\section{KAJIAN PUSTAKA}


Perilaku organisasi merupakan studi yang mempelajari tiga penentu perilaku dalam organisasi, yaitu individu, kelompok dan efek struktur terhadap perilaku untuk membuat organisasi bekerja lebih efektif (Robbins \& Judge, 2015). Perilaku organisasi berperan penting dalam menentukan produktivitas dan kinerja karyawan yang akan berdampak pada perusahaan. Ketika seorang karyawan merasa puas dalam bekerja, maka seorang karyawan akan berupaya semaksimal mungkin untuk menyelesaikan tugas maupun pekerjaannya dengan sebaik-baiknya. Dengan demikian apabila karyawan merasa puas dalam bekerja maka produktivitas dan hasil kerja karyawan akan meningkat secara optimal (Jaya, 2015). Perilaku organisasi mempelajari tiga penentu perilaku dalam organisasi, yaitu individu, kelompok, dan struktur. Selain itu, perilaku organisasi menerapkan pengetahuan yang diperoleh mengenai individu, kelompok, dan efek dari struktur terhadap perilaku untuk membuat organisasi bekerja dengan lebih efektif (Robbins \& Judge, 2015:6).

Perilaku organisasi adalah studi mengenai apa yang orang-orang lakukan dalam sebuah organisasi dan bagaimana perilaku mereka mempengaruhi kinerja organisasi. Oleh karena itu, perilaku organisasi sangat berpusat secara khusus pada situasi terkait pekerjaan, maka ia menekankan perilaku dalam hubungannya dengan pekerjaan, kerja, ketidakhadiran, perputaran pegawai, produktivitas, kinerja manusia, dan manajemen. Meskipun masih ada perdebatan mengenai kepentingan relatif masingmasing, perilaku organisasi mencakup topik inti motivasi, perilaku dan kekuasaan pemimpin, komunikasi interpersonal, struktur dan proses kelompok, pengembangan dan persepsi sikap, proses perubahan, konflik dan negosiasi, rancangan kerja (Robbins \& Judge, 2015:6).

\section{Kajian Teori Disiplin}

Perilaku organisasi merupakan ilmu perilaku terapan yang dibangun dan dikontribusikan dari sejumlah bidang perilaku disiplin. Disiplin merupakan sikap, tingkah laku dan perbuatan yang sesuai dengan peraturan perusahaan baik yang tertulis maupun yang tidak tertulis. Peraturan yang dimaksud termasuk absensi, lambat masuk, serta cepat pulang karyawan. Jadi hal ini merupakan suatu sikap indisipliner karyawan yang perlu disikapi dengan baik oleh pihak manajemen.

Disiplin kerja masuk dalam komponen masukan pada tingkat individu. Hal ini menunjukkan bahwa kedisiplinan seseorang dalam sebuah organisasi merupakan salah satu faktor dasar yang akan mempengaruhi berbagai hal yang berkaitan dengan proses yang akan terjadi (Robbins \& Judge, 2013).

Disiplin kerja merupakan suatu alat yang digunakan para manajer untuk berkomunikasi dengan karyawan agar mereka bersedia untuk mengubah suatu perilaku serta sebagai suatu upaya untuk meningkatkan kesadaran dan kesediaan seseorang mentaati semua peraturan perusahaan dan normanorma sosial yang berlaku (Veithzal Rivai, 2015:599). Indikator untuk mengukur variabel disiplin kerja karyawan dalam penelitian ini diadaptasi dari pendapat T. Hani Handoko (2008:208) antara lain:

1. Kehadiran : Tingkat kehadiran pegawai dalam organisasi.

2. Ketaatan : Tingkat kepatuhan terhadap peraturan yang ada dalam organisasi.

3. Ketepatan waktu : tingkat penyelesaian tugas dengan waktu yang telah diberikan.

4. Perilaku : Perilaku pegawai harus sesuai dengan peraturan dan norma yang ada di organisasi.

Pelanggaran kerja adalah setiap ucapan, tulisan, perbuatan seorang karyawan yang melanggar peraturan disiplin yang telah diatur oleh pemimpin organisasi. Sedangkan sanksi pelanggaran kerja adalah hukuman disiplin yang dijatuhkan pemimpin organisasi kepada pegawai yang telah melanggar peraturan disiplin yang telah diatur pimpinan organisasi (Veithzal Rivai dan Ella J. Sagala, 2011:450).

Veithzal Rivai dan Ella J. Sagala (2011:450) mengatakan ada beberapa tingkatan dan jenis sanksi pelanggaran kerja yang umumnya berlaku dalam suatu organisasi, yaitu :

1. Sanksi pelanggaran ringan, dengan jenis teguran lisan, teguran tertulis, pernyataan tidak puas secara tertulis.

2. Sanksi pelanggaran sedang, dengan jenis penundaan kenaikan gaji, penurunan gaji, penundaan kenaikan pangkat.

3. Sanksi dengan pelanggaran berat, dengan jenis penurunan pangkat, pembebasan dari jabatan , pemberhentian, dan pemecatan.

Adapun menurut Lijan Polta Sinambela (2012:249), terdapat tujuh faktor yang perlu dipertimbangkan apabila perusahaan menghendaki praktik-praktik disipliner yang wajar dan adil, faktorfaktor yang dapat membantu manajemen menganalisis masalah disiplin, yaitu :

1. Keseriusan permasalahan. Ketidak jujuran biasanya dianggap sebagai pelanggaran yang lebih serius dibandingkan pelaporan karena terlambat masuk 20 menit.

2. Lamanya masalah. Pelanggaran tidaklah berlangsung dalam kevakuman. Kejadian pertama biasanya dipandang berbeda dibandingkan dengan pelanggaran kedua atau ketiga. 
3. Pemberian sanksi harus konsisten. Pemberian sanksi kepada pegawai yang tidak disiplin harus konsisten. Ketidak konsistenan dalam memberikan sanksi dapat mengakibatkan pegawai merasa adanya diskriminasi pegawai, ringannya sanksi dan pengabaian disiplin.

4. Pemberian sanksi harus impersonal. Pemberian sanksi pelanggaran disiplin tidak membedakan golongan, tetapi diberlakukan sam sesuai dengan peraturan yang berlaku. Tujuannya agar pegawai menyadari bahwa disiplin organisasi untuk semua pegawai dengan sanksi pelanggaran yang sesuai dengan peraturan organisasi.

Sebagian besar orang bersedia menerima peraturan-peraturan perusahaan sebagai legitimasi apabila peraturan-peraturan tersebut adalah berkaitan dengan operasi-operasi yang efisien dan aman serta konsisten dengan konvensi-konvensi yang berlaku di tengah-tengah masyarakat. Hukuman-hukuman hendaknya wajar, hukuman yang sangat keras atas pelanggaran kecil tidak akan dianggap adil oleh pegawai. Peraturan-peraturan dan hukuman-hukuman yang tampaknya tidak masuk akal menciptakan sikap negatif terhadap disiplin dan menumbuhkan sikap tidak kooperatif diantara para pegawai (Lijan Polta Sinambela, 2012:249).

Dilihat dari perkembangan konsep disiplin ada dua dasar model disiplin menurut Suwatno (2013:230), yaitu disiplin berdasarkan tradisi (kuno) dan disiplin berdasarkan sasaran. Perbedaan kedua disiplin itu berpusat pada tujuan disiplin didalam perusahaan.

1. Disiplin Berdasarkan Tradisi (kuno)

Disiplin ini merupakan cara yang kuno, yaitu cara yang terdiri dari pendaftaran pelanggaran dan catatan dari hukuman dari setiap pelanggaran. Disiplin ini dilaksanakan secara kaku dan tegas tanpa kompromi atau cenderung penegakan disiplin secara otoriter. Tindakan disiplin ini diterapkan oleh atasan terhadap bawahan dan tidak pernah sebaliknya. Pada konsep ini disiplin dipandang sebagai suatu tindakan hukuman atau ganjaran akibat kesalahan-kesalahan yang dibuat oleh para karyawan dan tujuan dari disiplin ini adalah agar karyawan tersebut tidak lagi melakukan kesalahan dan merasa takut seandainya melakukan kesalahan lagi. Hal ini disebabkan beratnya hukuman yang diterima dan tujuan yang lainnya agar para karyawan yang lain akan merasa takut dan khawatir seandainya mereka melakukan kesalahan.

2. Disiplin Berdasarkan Sasaran

Disiplin berdasarkan sasaran bisa dianggap secara sah atau berlaku apabila dapat diterima secara sukarela oleh semua komponen didalam organisasi tersebut, apabila tidak dapat diterima secara sukarela maka secara otomatis disiplin tersebut tidak sah untuk diterapkan. Fungsi disiplin pada tipe ini adalah sebagai suatu fungsi pembentuk tingkah laku, bukan sebagai sistem hukuman.

\section{Kajian Teori Budaya Kerja}

Guna mengendalikan kedisiplinan pegawai agar mendapakan hasil yang maksimal maka perlu dilakukan inovasi pengendalian kualitas pekerjaan melalui penciptaan perilaku budaya kerja yang baik dalam bekerja pada setiap melaksanakan aktifitas. Budaya kerja dalam organisasi dapat diibaratkan seperti sebuah pedang bermata dua. Ia dapat menjadi faktor kunci keberhasilan dan dapat pula menjadi faktor utama kegagalan organisasi. Budaya kerja organisasi dapat mempengaruhi cara karyawan berperilaku (Taufiqqurrohman, 2016).

Pada tingkat organisasi, budaya kerja yang diberikan organisasi juga mampu mempengaruhi berbagai variabel yang berkaitan dengan proses yang dilakukan oleh individu, kelompok maupun organisasi (Robbins \& Judge, 2013). Budaya kerja adalah suatu pola asumsi dasar yang diciptakan, ditemukan, atau dikembangkan oleh kelompok tertentu sebagai pembelajaran untuk mengatasi masalah adaptasi eksternal dan integrasi internal yang terjadi dalam perusahaan, oleh karena itu diajarkan kepada anggotaanggota baru sebagai cara yang tepat untuk memahami, memikirkan, dan merasakan terkait dengan masalah-masalah tersebut (Schein, 2014: 17).

Unsur-unsur yang terkandung dalam budaya kerja menurut Yusran assagaf (2012) dapat diuraikan sebagai berikut :

1. Asumsi dasar

Dalam budaya kerja terdapat asumsi dasar yang dapat berfungsi sebagai pedoman bagi anggota maupun kelompok dalam organisasi untuk berperilaku.

2. Keyakinan yang dianut

Dalam budaya kerja terdapat keyakinan yang dianut dan dilaksanakan oleh para anggota perusahaan. Keyakinan ini mengandung nilainilai yang dapat berbentuk slogan atau motto, asumsi dasar, tujuan umum perusahaan, filosofi usaha, atau prinsip-prinsip menjelaskan usaha.

3. Pimpinan atau kelompok pencipta dan pengembangan budaya kerja.

Budaya kerja perlu diciptakan dan dikembangkan oleh pemimpin perusahaan atau kelompok tertentu dalam perusahaan tersebut.

4. Pedoman mengatasi masalah

Dalam perusahaan, terdapat dua masalah pokok yang sering muncul, yakni masalah adaptasi eksternal dan masalah integrasi internal. Kedua 
masalah tersebut dapat diatasi dengan asumsi dasar dan keyakinan yang dianut bersama anggota organisasi.

5. Berbagai nilai (sharing of value)

Dalam budaya kerja perlu berbagi nilai terhadap apa yang paling diinginkan atau apa yang lebih baik atau berharga bagi seseorang.

6. Pewarisan (learning process)

Asumsi dasar dan keyakinan yang dianut oleh anggota perusahaan perlu diwariskan kepada anggota-anggota baru dalam organisasi sebagai pedoman untuk bertindak dan berperilaku dalam perusahaan tersebut.

7. Penyesuaian (adaptasi)

Perlu penyesuaian anggota kelompok terhadap peraturan atau norma yang berlaku dalam kelompok atau organisasi tersebut, serta adaptasi perusahaan terhadap perubahan lingkungan.

Dimensi-dimensi yang digunakan untuk membedakan budaya kerja, menurut Robbins dan Judge (2016:256) ada tujuh karakteristik primer yang secara bersama-sama menangkap hakikat budaya organisasi, yaitu :

1. Inovasi dan pengambilan resiko. Sejauh mana para karyawan didorong untuk inovatif dan berani mengambil resiko.

2. Perhatian ke hal yang rinci. Sejauh mana para karyawan diharapkan mau memperlihatkan kecermatan, analisis, dan perhatian kepada rincian

3. Orientasi hasil. Sejauh mana manjemen focus pada hasil bukan pada teknik dan proses yang digunakan untuk mendapatkan hasil itu.

4. Orientasi orang. Sejauh mana keputusan manajemen memperhitungkan efek hasil pada orang-orang di dalam organisasi itu.

5. Orientasi tim. Sejauh mana kegiatan kerja diorganisasikan dalam tim-tim kerja, bukannya individu.

6. Keagresifan. Sejauh mana orang-orang itu agresif dan kompetitif, bukan bersantai.

7. Kemantapan. Sejauh mana kegiatan organisasi menekankan dipertahankannya status sebagai lawan dari pertumbuhan atau inovasi.

Budaya kerja membedakan antara organisasi satu dengan yang lainnya, hal itu dikarenakan landasan dan sikap perilaku yang dicerminkan oleh setiap orang dalam organisasi berbeda. Budaya kerja yang terbentuk secara positif akan bermanfaat karena setiap anggota dalam suatu organisasi membutuhkan ruang lingkup yang positif dalam pekerjaannya demi kemajuan diorganisasi tersebut, namun budaya kerja akan berakibat buruk jika pegawai dalam suatu organisasi terdapat perbedaaan baik dalam cara pandang, pendapat, tenaga dan pikirannya.
Untuk memperbaiki budaya kerja yang baik membutuhkan waktu untuk merubahnya, maka untuk itu perlu adanya pembenahan-pembenahan yang dimulai dari sikap dan tingkah laku pemimpinannya sebagai terdahulu kemudian diikuti para bawahannya. Terbentuknya budaya kerja diawali tingkat kesadaran pemimpin karena besar hubungan anta pemimpinan dengan bawahan sangat menentukan cara tersendiri apa yang dijalankan dalam perangkat satuan kerja dalam organisasi. Tubagus A. Darodjat (2014) mengungkapkan makna setiap nilai budaya, antara lain menimbulkan :

1.Disiplin, perilaku yang senatiasa berpijak pada peraturan dan norma yang berlaku diorganisasi. Disiplin meliputi ketaatan terhadap peraturan perundang-undangan, prosedur, waktu bekerja, berinteraksi dengan mitra dan sebagainya.

2.Keterbukaan, kesiapa untuk memberikan dan menerima informasi yang benar dari dan kepada sesama mitra kerja untuk kepentingan organsiasi.

3.Saling menghargai, perilaku yang menunjukan pengahargaan terhadap individu, tugas dan tanggung jawab orang lain sesama mitra kerja.

4.Kerjasama, kesediaan untuk memberi dan menerima kontribusi dari dan atau kepada mitra kerja dalam mencapai sasaran dan target perusahaan.

Faktor-faktor utama yang menentukan kekuatan budaya kerja menurut Suyadi $(2013: 181)$ adalah:

1. Kebersamaan

Kebersamaan adalah sejauh mana anggota organisasi mempunyai nilai-nilai inti yang dianut secara bersama. Derajat kebersamaan dipengaruhi oleh unsur orientasi dan imbalan. Orientasi dimaksudkan pembinaan kepada anggota-anggota organisasi khususnya anggota baru maupun melalui program-program latihan. Melalui program orientasi, anggota-anggota baru organisasi diberi nilai-nilai budaya yang perlu dianut secara bersama oleh anggota-anggota organisasi. Disamping orientasi kebersamaan, juga dipengaruhi oleh imbalan dapat berupa kenaikan gaji, jabatan (promosi), hadiah-hadiah, tindakan-tindakan lainnya yang membantu memperkuat komitmen nilai-nilai inti budaya kerja.

2. Intensitas

Intensitas adalah derajat komitmen dari anggotaanggota perusahaan kepada nilai-nilai inti budaya kerja. Derajat intensitas bisa merupakan suatu hasil dari struktur imbalan. Oleh karena itu, pimpinan perusahaan perlu memperhatikan dan mentaati struktur imbalan yang diberikan kepada anggota-anggota perusahaan guna menanamkan nilai-nilai budaya kerja. 
Dalam melaksanakan program budaya kerja dan manajemen modern diperlukan banyak kreatifitas dan kombinasi dari ilmu pengetahuan dan teknologi. Salah satu yang paling mendasar adalah penguasaan atas nilai-nilai yang patut diangkat dalam administrasi/manajemen dalam rangka menghadapi barbagai macam tantangan yang sedang berjalan maupun yang akan datang. Budaya kerja memiliki pengaruh yang signifikan terhadap peningkatan mutu atau kualitas kerja pegawai. Logika budaya kerja sebagai memiliki pengaruh yang kuat terhadap kinerja (pegawai) adalah meliputi tiga gagasan (Heskett, J. L., Sasser, E. W., \& Wheeler, 2008), yaitu: pertama, adalah penyatuan tujuan. Dalam sebuah perusahaan (organisasi) dengan budaya yang kuat, karyawan cenderung berbaris mengikuti penabuh genderang yang sama. Artinya, tidak ada prestasi kecil dalam suatu dunia yang penuh spesialisasi dan bentuk-bentuk keragaman lain. Kedua, budaya yang kuat juga sering dikatakan membantu kinerja bisnis karena menciptakan suatu tingkat motivasi yang luar biasa dalam diri para karyawan. Ketiga, budaya kuat juga dikatakan membantu kinerja karena memberikan struktur dan kontrol yang dibutuhkan tanpa harus bersandar pada birokrasi formal yang mencekik yang dapat menekan tumbuhnya motivasi dan inovasi.

\section{Kajian Teori Perilaku Kewargaan Organisasional}

Perilaku kewargaan organisasional berada pada level tingkat kelompok. Tingkatan kelompok merupakan dinamika perilaku kelompok dan faktorfaktor determinannya. Perilaku warga organisasi sebagai perilaku pilihan yang tidak menjadi bagian dari kewajiban kerja formal karyawan, namun mendukung berfungsinya organisasi tersebut secara efektif (Robbins \& Judge, 2013).

Perilaku kewargaan organisasional berkaitan dengan kontribusi perilaku diskresioner bahwa anggota (misalnya, karyawan membalas organisasi mereka), Kualifikasi "diskresi" menyampaikan gagasan bahwa perilaku seperti itu bukan juga bagian dari deskripsi pekerjaan atau dimensi persyaratan kerja yang tidak dapat dengan mudah diukur (misalnya, "bekerja sama dengan rekan-rekan") atau diberlakukan atas beberapa tingkat minimal (seperti absensi atau ketepatan waktu) (Organ, 2015: 317).

Organ dalam Tambe \& Shanker (2014:68) mengidentifikasi lima dimensi perilaku kewargaan organisasional, yaitu: a) Altruism, b) Courtesy, c) Conscientiousness, d) Sportsmanship, dan e) Civil Virtue. Penelitian ini menggunakan indikator yang digunakan Organ dalam Tambe \& Shanker (2014:68), yaitu meliputi :

1. Altruism (perilaku membantu)
Merupakan sikap sukarela dari seorang karyawan untuk membantu karyawan lain yang sedang mengalamai kesulitan dalam organisasi tanpa mengharapkan balasan atau imbalan.

2. Courtesy (sikap kesopanan)

Merupakan perilaku kooperatif untuk mencegah dari timbulnya masalah yang berhubungan dengan pekerjaan.

3. Conscientiousness (sikap kesadaran)

Merupakan tingkat kepekaan individu atau seorang karyawan terhadap apa yang menjadi tanggung jawabnya pada pekerjaan dan organisasi.

4. Sportmanship (sikap sportif)

Sikap untuk mentolerir masalah yang bersifat sepele, dan tidak saling menyalahkan dengan karyawan lain agar dapat menjaga suasana yang kondusif dalam organisasi.

5. Civic Virtue (kebajikan sipil)

Kebajikan sipil ini merupakan sikap untuk dapat ikut berpartisipasi aktif dalam melaksanakan kebijakan organisasi agar lebih efektif, baik melalui pendapat maupun tindakan.

Seperti halnya sebagian besar perilaku yang lain, perilaku kewargaan organisasi (organizational citizenship behavior) ditentukan oleh banyak hal artinya tidak ada penyebab tunggal dalam perilaku kewargaan organisasional (organizational citizenship behavior). Sesuatu yang masuk akal apabila menerapkan perilaku kewargaan organisasional secara rasional, yaitu salah satunya dengan pendekatan motif dalam perilaku organisasi. McClelland (Hardaningtyas, 2015:14) mengemukakan bahwa manusia memiliki 3 tingkatan motif, yaitu :

1. Motif Berprestasi

Mendorong orang untuk menunjukkan suatu standar istimewa (excellence), mencari prestasi dari tugas, kesempatan atau kompetisi.

2. Motif Afiliasi

Mendorong orang untuk mewujudkan, memelihara, dan memperbaiki hubungan dengan orang lain.

3. Motif Kekuasaan

Mendorong orang untuk mencari status dan situasi dimana mereka dapat mengontrol pekerjaan atau tindakan orang lain.

Berdasarkan penjelasan mengenai pengaruh karakteristik pekerjaan terhadap kepuasan kerja serta implikasinya terhadap kinerja karyawan maka disusun sebuah paradigma pengaruh karakteristik pekerjaan terhadap kepuasan kerja serta implikasinya terhadap kinerja karyawan secara jelas digambarkan dalam Gambar 1.1 sebagai berikut:

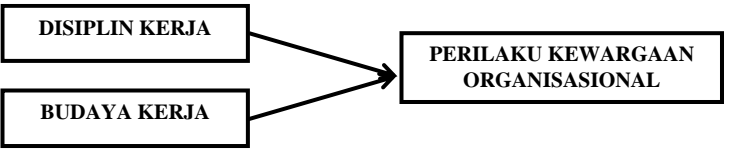




\section{GAMBAR 1.1 \\ PARADIGMA PENELITIAN METODE PENELITIAN}

Penelitian ini dilakukan untuk mengetahui pengaruh disiplin kerja dan budaya kerja terhadap perilaku kewargaan organisasional PT. INTI (Persero). Variabel bebas (independent variable) yang pertama pada penelitian ini adalah $\left(\mathrm{X}_{1)}\right.$ disiplin dengan dimensi (1) kehadiran (2), ketaatan, (3) ketepatan waktu, dan (4) perilaku, dan $\left(\mathrm{X}_{2}\right)$ budaya kerja dengan (1) inovasi dan keberanian mengambil resiko, (2) perhatian secara detail, (3) berorientasi pada hasil, (4) berorientasi pada manusia, (5) berorientasi tim, (6) agresifitas, (7) stabilitas. Masalah penelitian yang merupakan dependent variabel atau variabel terikat adalah perilaku kewargaan organisasional dengan dimensi yang terdiri dari (1) altruism (perilaku membantu), (2) courtesy (sikap kesopanan), (3) conscientiousness (sikap lebih berhati-hati), (4) sportmanship (sikap sportif), dan (5) civic virtue (kebajikan sipil).

Objek/unit analisis pada penelitian ini yaitu karyawan PT. INTI (Persero) yang berjumlah 605 orang. Penelitian ini dilakukan pada kurun waktu kurang dari satu tahun, sehingga teknik pengumpulan data yang digunakan pada penelitian ini adalah crosssectional method. Teknik pengumpulan data yang digunakan adalah studi kepustakaan, studi lapangan dengan penyebaran kuesioner secara langsung ke perusahaan dan studi literatur. Sedangkan teknik analisis data yang dilakukan adalah analisis deskriptif. Metode penelitian yang digunakan adalah metode explanatory survey.

\section{HASIL PENELITIAN DAN PEMBAHASAN Gambaran Disiplin Kerja pada PT. INTI (Persero)}

Disiplin kerja merupakan suatu alat yang digunakan para manajer untuk berkomunikasi dengan karyawan agar mereka bersedia untuk mengubah suatu perilaku serta sebagai suatu upaya untuk meningkatkan kesadaran dan kesediaan seseorang mentaati semua peraturan perusahaan dan normanorma sosial yang berlaku (Veithzal Rivai, 2015: 599). Dimensi disiplin kerja karyawan dalam penelitian yang akan dilakukan menurut T. Hani Handoko (2008:208) yaitu kehadiran, ketaatan, ketepatan waktu, dan perilaku.

TABEL 1.1

\begin{tabular}{lllll}
\multicolumn{5}{c}{ REKAPITULASI VARIABEL DISIPLIN } \\
\hline No & Dimensi & $\begin{array}{l}\text { Total } \\
\text { Skor }\end{array}$ & $\begin{array}{l}\text { Skor } \\
\text { Ideal }\end{array}$ & $\%$ \\
\hline
\end{tabular}

\begin{tabular}{llccc}
\hline 1 & Kehadiran & 1352 & 1890 & $71,5 \%$ \\
2 & Ketaatan & 1542 & 2520 & $61,2 \%$ \\
3 & Ketepatan & 1619 & 2520 & $64,2 \%$ \\
4 & waktu Perilaku & 2089 & 3150 & $66,3 \%$ \\
\hline & Total & $\mathbf{6 6 0 2}$ & $\mathbf{1 0 0 8 0}$ & $\mathbf{6 5 , 5 \%}$ \\
\hline
\end{tabular}

Berdasarkan tabel aspek disiplin karyawan paling tinggi yaitu terdapat pada dimensi kehadiran memperoleh skor sebesar 1352 atau $71,5 \%$. Sementara dimensi paling rendah yaitu pada dimensi ketaatan yang memperoleh skor sebesar 1542 atau $61,2 \%$. Secara keseluruhan variabel disiplin kerja karyawan memperoleh skor 6602. Apabila dipresentasekan kedalam skor ideal maka diperoleh presentase sebesar 65,5\%, dapat dikatakan menurut Moch. Ali (2013:184) bahwa sebagian besar responden menyatakan disiplin kerja karyawan pada PT. INTI (Persero) dalam kategori cukup tinggi.

Skor ideal variabel disiplin kerja sebesar 10080 untuk 16 item pernyataan. Perolehan skor berdasarkan hasil pengelolaan data pada variabel disiplin kerja adalah 6602 atau 65,5\%. Skor tersebut secara kontinum dapat digambarkan sebagai berikut:

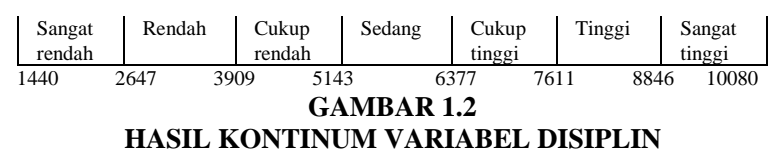

Skor nilai pada disiplin kerja di PT. INTI (Persero) dengan data penelitian yaitu termasuk dalam kategori cukup tinggi. Hal ini menunjukkan penerapan kehadiran, ketaatan, ketepatan waktu, dan perilaku pada disiplin kerja dikatakan cukup baik sehingga masih perlu ditingkatkan lagi karena semua dimensi masih berada dibawah skor ideal.

\section{Gambaran Budaya Kerja pada PT. INTI (Persero)}

Budaya kerja adalah pandangan hidup sebagai nilai-nilai dan sifat, kebiasaaan yang mengakut moral, sosial dan norma-norma perilaku yang mendasarkan pada kepercayaan kemampuan dan prioritas seseorang. Pada tingkat organisasi, budaya kerja yang diberikan organisasi juga mampu mempengaruhi berbagai variabel yang berkaitan dengan proses yang dilakukan oleh individu, kelompok maupun organisasi. Selanjutnya, dalam penelitian ini dimensi budaya kerja yang dipakai adalah menurut Robbins dan Judge (2016:256) yaitu inovasi dan pengambilan resiko, perhatian ke hal yang rinci, orientasi hasil, orientasi orang, orientasi tim, keagresifan, dan kemantapan.

TABEL 1.2

REKAPITULASI VARIABEL BUDAYA KERJA 


\begin{tabular}{llccc}
\hline No & \multicolumn{1}{c}{ Dimensi } & $\begin{array}{c}\text { Total } \\
\text { Skor }\end{array}$ & $\begin{array}{c}\text { Skor } \\
\text { Ideal }\end{array}$ & \% \\
\hline 1 & $\begin{array}{l}\text { Inovasi dan } \\
\text { pengambilan }\end{array}$ & 1260 & 1260 & $66,9 \%$ \\
2 & & 1250 & 1890 & $66,1 \%$ \\
& $\begin{array}{l}\text { resiko } \\
\text { Perhatian ke hal }\end{array}$ & & & \\
3 & yang rinci & 949 & 1260 & $75,3 \%$ \\
4 & Orientasi hasil & 887 & 1260 & $70,4 \%$ \\
5 & Orientasi orang & 383 & 630 & $60,8 \%$ \\
6 & Orientasi tim & 411 & 630 & $65,2 \%$ \\
7 & Keagresifan & 1288 & 1890 & $68,1 \%$ \\
& Kemantapan & & & \\
\hline \multicolumn{2}{c}{ Total } & $\mathbf{6 4 2 8}$ & $\mathbf{8 8 2 0}$ & $\mathbf{7 2 . 9 \%}$ \\
\hline
\end{tabular}

Berdasarkan tabel aspek budaya kerja karyawan paling tinggi yaitu terdapat pada dimensi orientasi hasil memperoleh skor sebesar 949 atau $75,3 \%$. Sementara dimensi paling rendah yaitu pada dimensi orientasi tim yang memperoleh skor sebesar 383 atau $60,8 \%$. Secara keseluruhan variabel budaya kerja karyawan memperoleh skor 6428. Apabila dipresentasekan kedalam skor ideal maka diperoleh presentase sebesar $72,9 \%$, dapat dikatakan menurut Moch. Ali (2013:184) bahwa sebagian besar responden menyatakan budaya kerja karyawan pada PT INTI (Persero) dalam kategori cukup tinggi.

Skor ideal variabel budaya kerja sebesar 8820 untuk 14 item pernyataan. Perolehan skor berdasarkan hasil pengelolaan data pada variabel budaya kerja adalah 6428 atau $72,9 \%$. Skor tersebut secara kontinum dapat digambarkan sebagai berikut:

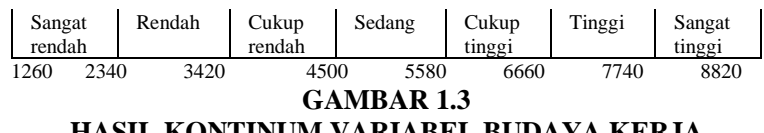

HASIL KONTINUM VARIABEL BUDAYA KERJA

Skor nilai pada budaya kerja di PT. INTI (Persero) dengan data penelitian yaitu termasuk dalam kategori cukup tinggi. Hal ini menunjukkan penerapan inovasi dan pengambilan resiko, perhatian ke hal yang rinci, orientasi hasil, orientasi orang, orientasi tim, keagresifan, dan kemantapan pada budaya kerja dikatakan cukup baik sehingga masih perlu ditingkatkan lagi karena semua dimensi masih berada dibawah skor ideal.

\section{Gambaran Perilaku Kewargaan Organisasional Karyawan pada PT. INTI (Persero)}

Setiap organisasi berusaha mencapai tujuannya dengan menggunakan segenap sumber daya manusia yang dimilikinya. Oleh karenanya, tujuan setiap sumber daya manusia harus dijaga agar selaras dengan tujuan organisasi. Di samping itu, sumber daya manusia dalam organisasi di harapkan memiliki kompetensi, kemapuan dan keterampilan yang diperlukan untuk melaksanakan tugasnya, karena kemampuan dan keterampilan setiap individu dalam organisasi berbeda-beda, hal tersebut dapat terlihat dari perilaku individu dalam organisasi. Perilaku organisasi kewargaan adalah perilaku kerja karyawan diluar tugas dari deskripsi pekerjaannya yang secara tidak langsung tidak dihargai namun bisa membawa keefektifan dalam pencapaian tujuan organisasi. Organ dalam Tambe \& Shanker (2014: 68) mengidentifikasi lima dimensi OCB, yaitu: a) Altruism, b) Courtesy, c) Conscientiousness, d) Sportsmanship, dan e) Civil Virtue.

TABEL 1.3

REKAPITULASI VARIABEL PERILAKU KEWARGAAN ORGANISASIONAL

\begin{tabular}{ccccc}
\hline No & \multicolumn{1}{c}{ Dimensi } & $\begin{array}{c}\text { Total } \\
\text { Skor }\end{array}$ & $\begin{array}{c}\text { Skor } \\
\text { Ideal }\end{array}$ & $\mathbf{\%}$ \\
\hline 1 & Altruism & 1224 & 1890 & $64,8 \%$ \\
2 & Courtesy & 1756 & 2520 & $69,7 \%$ \\
3 & Conscientiousness & 1677 & 2520 & $66,5 \%$ \\
4 & Sportsmanship & 1780 & 2520 & $70,6 \%$ \\
5 & Civil Virtue & 2740 & 4410 & $62,1 \%$ \\
\hline & Total & $\mathbf{9 1 7 7}$ & $\mathbf{1 3 8 6 0}$ & $\mathbf{6 6 , 2 \%}$ \\
\hline
\end{tabular}

Berdasarkan tabel aspek perilaku kewargaan organisasional paling tinggi yaitu terdapat pada dimensi Sportsmanship memperoleh skor sebesar 1780 atau $70,6 \%$. Sementara dimensi paling rendah yaitu pada dimensi Civil Virtue yang memperoleh skor sebesar 2740 atau $62,1 \%$. Secara keseluruhan variabel perilaku kewargaan organisasional memperoleh skor 9177. Apabila dipresentasekan kedalam skor ideal maka diperoleh presentase sebesar 66,2\%, dapat dikatakan menurut Moch. Ali (2013:184) bahwa sebagian besar responden menyatakan perilaku kewargaan organisasional pada PT. INTI (Persero) dalam kategori cukup tinggi.

Skor ideal variabel perilaku kewargaan organisasional sebesar 13860 untuk 22 item pernyataan. Perolehan skor berdasarkan hasil pengelolaan data pada variabel perilaku kewargaan organisasional adalah 9177 atau 66,2\%. Skor tersebut secara kontinum dapat digambarkan sebagai berikut:

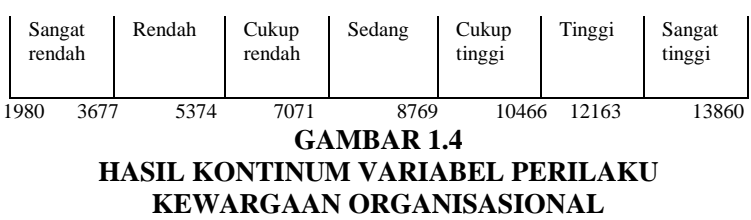

Skor nilai pada perilaku kewargaan organisasional di PT. INTI (Persero) dengan data penelitian yaitu termasuk dalam kategori cukup tinggi. Hal ini menunjukkan penerapan Altruism, Courtesy, Conscientiousness, Sportsmanship, dan Civil Virtue 
pada perilaku kewargaan organisasional dikatakan cukup baik sehingga masih perlu ditingkatkan lagi karena semua dimensi masih berada dibawah skor ideal.

\section{KESIMPULAN DAN REKOMENDASI Kesimpulan}

Berdasarkan pembahasan teori, hasil penelitian, dan pengujian analisis korelasi multipel yang dilakukan mengenai pengaruh disiplin kerja dan budaya kerja terhadap perilaku kewargaan organisasional pada PT. INTI (Persero) dapat disimpulkan sebagai berikut:

1. Gambaran disiplin kerja di PT. INTI (Persero) berada pada kategori sudah sesuai. Hal ini dapat dilihat dari dimensi yang tertinggi hingga terendah. Dimensi disiplin kerja yang memiliki penilaian cukup tinggi adalah dimensi kehadiran, sedangkan dimensi yang memiliki penilaian yang sangat rendah adalah dimensi ketaatan. Sehingga dapat disimpulkan bahwa disiplin kerja di PT. INTI (Persero) sebagian besar sudah sesuai.

2. Gambaran budaya kerja karyawan di PT. INTI (Persero) berada pada kategori efektif. Hal ini dapat dilihat dari dimensi yang memiliki penilaian sangat tinggi adalah dimensi berorientasi pada manusia, sedangkan dimensi yang memiliki penilaian yang sangat rendah adalah dimensi berorientasi pada tim. Sehingga dapat disimpulkan bahwa budaya kerja di PT. INTI (Persero) cukup baik.

3. Gambaran perilaku kewargaan organisasional karyawan di PT. INTI (Persero) berada pada kategori tinggi. Hal ini dapat dilihat dari dimensi yang tertinggi hingga terendah. Dimensi Courtesy (Sikap Kesopanan) memiliki penilaian yang sangat tinggi, sedangkan yang terendah yaitu dimensi Civic Virtue (Kebajikan Sipil). Sehingga dapat disimpulkan bahwa perilaku kewargaan organisasional karyawan di PT. INTI (Persero) sudah cukup tinggi.

\section{Rekomendasi}

Berdasarkan hasil penelitian, maka penulis menyarankan beberapa hal mengenai disiplin kerja dan budaya kerja untuk meningkatkan perilaku kewargaan organisasional, yaitu sebagai berikut:

1. Dalam penerapan disiplin, perusahaan perlu mempertahankan sanksi hukuman bagi karyawan yang datang terlambat dan pulang sebelum waktunya, pengawasan melekat dari pimpinan, keadilan, hubungan sesama karyawan dan ketegasan perusahaan (baik bentuk sanksi hukuman maupun pimpinan) bagi perilaku karyawan indisipliner dan memberikan penghargaan bagi karyawan yang disiplin sehingga karyawan merasa dihargai keberadaanya.

2. Pimpinan diharapkan dapat meningkatkan perilaku kewargaan organisasional dengan meningkatkan budaya organisasi yakni: adanya harapan positif, kesempatan bertindak, melakukan komunikasi, membina hubungan sosial, dan adanya anggapan positif.

3. Untuk meningkatkan perilaku kewargaan organisasional, perusahaan perlu mengadakan acara kebersamaan seperti, makan bersama, malam keakraban, Family Gathering dan sebagainya. alangkah baiknya karyawan bersedia meluangkan sedikit waktu untuk bekerja diluar job deskripsi, membantu rekan lain yang kesulitan dalam menyelesaikan pekerjaan dengan cara perusahaan memberikan teladan dan pengarahan lebih dulu sehingga karyawan merasa peduli di linkungan perusahaan.

\section{DAFTAR PUSTAKA}

A. Anwar Prabu Mangkunegara, 2015, Manajemen Sumber Daya Manusia. Perusahaan, Penerbit Bandung : Remaja Rosdakarya.

Abdallah Taamneh, 2015.'The Impact of Practicing Interactional Justice on Employees Organizational Citizenship Behavior (OCB) in the Jordanian Ministry of Justice”, Graduate School of Business, Girne American University, Turkey.

Abdus Salam, 2014, Manajemen Insani Dalam Bisnis, Pustaka Pelajar, Yogyakarta.

Armstrong, S. (2014). Human Resource Management practice. (michael armstrong, Ed.) (13th ed.). London.

Aslam. Rabia., \& Saqadat. Shama,. 2011. Investigating the Relationship of Organizational Justice on Organizational Citizenship Behavior among Teaching Staff of University of the Punjab. European Journal of Scientific Research. Vol.57. No.1. pp. 53-67

Aslam. Rabia., \& Saqadat. Shama,. 2011. Investigating the Relationship of Organizational Justice on Organizational Citizenship Behavior among Teaching Staff of University of the Punjab. European Journal of Scientific Research. Vol.57. No.1. pp. 53-67.

Ating Somantri dan Sambas Ali Muhidin, 2006, Aplikasi Statistika Dalam Penelitian,. Penerbit Pustaka Setia, Bandung.

Berbaoui Kamel, 2015."Relationship between Job Satisfaction and Organizational Citizenship Behavior in the National Company for Distribution of Electricity and Gas", Faculty of 
Journal of Business Management Education | Volume 3, Number 2, September 2018, page. 115-125

economic and commercial sciences, management, Bechar University - Algeria.

Collins Agyemang Badu, 2013."Perceived Organizational Justice and Employees' Organizational Citizenship Behaviour in Ghana”, Department of Business Administration, University of Professional Studies, Ghana.

Coyle, Hoque, kessler, 2013."Human Resource Management". Economics, Management, Finance and the social Sciences, University of London.

Darmawan, Didit. 2013. Prinsip-PrinsipPerilaku Organisasi. Penerbit JP. Books. Surabaya.

Dhiman Deb Chowdury, 2015."Deviant Citizenship Behavior : A Comprehensive Framework towards Behavioral Excellence in Organizations", East Asian Journal of Business Management.

Dikshit. A. Y., \& Dikshit. P. A,. 2014. An Investigation in Organizational Citizenship Behavior of Managers As Perceived By Senior Officers with Leadership Roles \& Responsibilities. International Journal of Advance Research in Computer Science and Management Studies. Vol.2. Issue 2. 47-51.

Endang Sri Rahayu, 2017, Pengaruh Budaya Kerja, Integritas Dan Kepercayaan Terhadap Organizational Citizenship Behavior Pada Dosen Universitas Negeri Jakarta, Econo Sains Volume XV, Nomor 1, e-issn: 2252-8490, Maret 2017.

Endang, Setyaningdyah. 2013. The Effect Of Human Resource Competence,. Organisational Commitement And Transactional Leadership On Work Dicipline, Job Satisfaction Employee's Performance. Interdiciplinary, Journal of Contemporary Research in Business. Vol.5. No.4.

F.H. Abdul Rauf, 2014. "Perception of Organizational Justice as a Predictor of Organizational Citizenship Behavior: An Empirical Study at Schools in Sri Lanka”, Department of Management, South Eastern University, Sri lanka.

Faisal Qadeer, 2016.'Linking Passion to Organizational Citizenship Behavior and Employee Performance : The Mediating Role of Work Engagement", The University of Labore, Pakistan.

Ferris, D. L., Lian, H., Brown, D., \& Morrison, R. (2015). "Ostracism, self-esteem, and job performance: When do we self-verify and when do we self-enhance?". Academy of Management Journal, 58, 279-297.
Ghozali, Imam. 2006. Aplikasi Analisis Multivariate Dengan Sess. Cetakan keempat. Badan Penerbit Universitas Diponegoro. Semarang.

Hadari Nawawi, 2013, Manajemen Sumber Daya Manusia, Yogyakarta: Gajah Mada Press.

Hans. Arvind., Mubeen. Soofi. A., \& Al-Badi. Ameera. H. H,. 2015. Antecedents of Organizational Citizenship Behavior (OCB) in Banking Sector of Sultanate Oman. International Journal in Management and Social Science, Vol.03. Issue 01

Hassan Ali Khan, 2014"Impacts of Corporate Social Responsibility on Employees Behavior in Telecom sector of Pakistan", Army Public College of Management and Sciences (APCOMS), Pakistan.

Hermayanti, 2015.'Pengaruh Budaya Kerja terhadap Komitmen Karyawan PT. Indofood CBP Sukses Makmur Tbk Cabang Bandung Divisi Noodle" Fakultas Ekonomi dan Manajemen, Universitas IPB Bogor.

Judeh. Mahfuz,. 2012. Examining the Relationship between Organizational Justice, Job Security, and Organizational Citizenship Behavior in the Jordanian Bank: A Structural Equation Modeling Perspective. Jordan Journal of Business Administration, Vol.8. No.3. 581-602.

Khaerul Umam, 2013, Perilaku Organisasi. Bandung: Pustaka Setia.

Kreitner, Robert dan Kinicki, Angelo. 2014.”Alih bahasa oleh Biro Bahasa Alkemis. Perilaku Organisasi (9 th ed)". Jakarta: Salemba empat.

Kurniawan D, Lubis AR, Adam M. 2012. "Pengaruh budaya kerja dan disiplin kerja kerja terhadap perilaku kewargaan organisasional Internasional Federation Red Cross Banda Aceh”. Jurnal Ilmu Manajemen

Liu, J., Kwan, H. K., Lee, C., \& Hui, C. (2013). Workto-family spillover effects of workplace ostracism: The role of work-home segmentation preferences. Human Resource Management, 52, 75-93.

Mariman Darto, 2015."The Effect of Transformational Leadership, Religiosity, Job Satisfaction, and Organizational Culture on Organizational Citizenship Behavior and Employee Performance in the Regional Offices of National Institute of Public Administration, Republic of Indonesia”, Doctoral Student of Management Studies, Economics Faculty, Mulawarman University, Indonesia.

Mondy, R.W., \& Noe, R. M. 2011. Human Resource Management. Massachusetts: Prentice Hal.

Mustafa Edwin Nasution dan Hardius Usman.2012. Proses Penelitian Kuantitatif. Jakarta: Fakulatas Ekonomi UI. 
Journal of Business Management Education | Volume 3, Number 2, September 2018, page. 115-125

Naveed R. Khan. 2013.'Leadership Styles and Organizational Citizenship Behavior in Small and Medium Scale Firms". Faculty of Management and Economics, Universitas Pendidikan Sultan Idris, Malaysia.

Noruzy. A., Shatery. K., Rezazadeh. A., \& Shirkouhi,. 2011. Investigation the relationship between organizational justice, and organizational citizenship behavior: The mediating role of perceived organizational support. Indian Journal of Science and Technology.Vol. 4. No.7

Pervashnee, Naido dan Martins, Nico. (2014). "Investigating The Relationship Between Organizational Culture And Work Engagement", 12, 1-9.

Professor Mohammad Shehada, 2015. "The Relationship between Managers' Level-Five Leadership Style and their Employees' Organizational Citizenship Behavior in the Telecommunication Companies in Jordan", European Journal of Business and Management, ISSN 2222-1905 (Paper) ISSN 2222-2839 (Online) Vol.7, No.9.

Rabindra Kumar Pradhan, 2016. "Impact of psychological capital on organizational citizenship behavior: Moderating role of emotional intelligence". Department of Humanities of Technology, India.

Rivai, Veithzal dan Ella Djauhari Sagala, 2013, Manajemen Sumber Daya Manusia Untuk Perusahaan, Rajawali Pers, Jakarta.

Robbins, 2013."Essentials of Organizational Behavior, 11th ed." (Prentice Hall, 2013).

Robbins, Stephen P dan Timothy A Judge. 2014. Perilaku Organisasi. Jakarta: Salemba Empat

Rosita Edy Haryanti, Pantja Djati, dan S. Josephine Tobing, 2014, Analisis Hubungan Disiplin kerja Dan Disiplin Kerja Dengan Organizational Citizenship Behavior (OCB) PT. Toshiba Consumer Products Indonesia, Jurnal Ilmiah, Buletin Ekonomi ISSN: 1410-3842, Volume 18 No.2 Agustus 2014.

S.P, Hasibuan, Malayu. 2013. Manajemen Sumber Daya Manusia. Jakarta: PT. Bumi Aksara.

Samanvitha Swaminathan, 2013."Job Satisfaction as a Predictor of Organizational Citizenship Behavior : An Empirical Study", Bharathidasan Institue of Management, India.

Schein, Edgar H. 2014. Organizational Culture and Leadership. San Francisco: Josey-Bass Publishers.

Setyo Sardjono, 2014. "The Effect of Transformational Leadership, Superior-Subordinate Relationship, Job Satisfaction and Willing Cooperation towards Organizational Citizenship Behavior and Employee Performance", Lecturer of
Administrative Science Faculty, Brawijaya University, Malang.

Sinambela, Lijan. 2012. Kinerja Pegawai: Teori, Pengukuran dan Implikasi. Yogyakarta: Graha Ilmu

Sugiyono, 2012, Metode Penelitian Kuantitatif Kualitatif dan R\&D. Bandung: Alfabeta

Sugiyono, 2014, Metode Penelitian Kuantitatif, Kualitatif, dan Kombinasi (Mixed. Methods). Bandung : Alfabeta

Sugiyono, 2015, Metode Penelitian Pendidikan (Pendekatan Kuantitatif, Kualitatif dan R\&D). Penerbit CV. Alfabeta: Bandung

Taliziduhu Ndraha, 2014, Budaya Organisasi, Jakarta : Rineka Cipta

Tambe. S., \& Shanker. M,. 2014. A Study of Organizational Citizenship Behaviour (OCB) and ItsDimensions: A Literature Review. International Research Journal of Business and Management. Vol. 1. 67-73

Trisia, 2014.’Pengaruh Budaya Organisasi terhadap Organizational Citizenship Behavior (OCB) pegawai tetap di kantor Pusat PT. Garuda Indonesia (Persero) Tbk”. FISIP, Universitas Indonesia.

Tubagus A. Darodjat, 2014, Pentingnya Budaya Kerja Tinggi dan Budaya Kerja Kuat. PT Refika Aditama, Bandung

Ulku, H., \& Pamukcu, M. T. (2015). "The impact of $R$ $\& D$ and knowledge diffusion on the productivity of manufacturing firms in Turkey". Journal of Productivity Analysis, 44(1), 79-95.

Wibowo, 2014. Manajemen Kinerja, Edisi keempat, Rajawali Pers, Jakarta.

Wilson Bangun, 2012, Manajemen Sumber Daya Manusia, Erlangga, Bandung

Zahra Alizadeh, 2012."Antecendents and Consequences of Organizational Citizenship Behavior (OCB)", Payam Noor University, Iran. 